JRPB, Vol. 7, No. 2, September 2019, Hal. 221-229

DOI: $10.29303 /$ jrpb.v7i2.138

ISSN 2301-8119, e-ISSN 2443-1354

Tersedia online di http://jrpb.unram.ac.id/

\title{
KERAGAAN HASIL ANALISIS PROKSIMAT BIJI KELOR (Moringa oleifera Lam.) PADA BERBAGAI TEKNIK PENGERINGAN BIJI
}

\author{
Performance of Proximate Analysis of Moringa (Moringa oleifera Lam.) Seeds \\ on Various Seed Drying Techniques
}

\author{
Bambang Budi Santoso ${ }^{1, *)}$, IGM Arya Parwata ${ }^{1}$, Jayaputra ${ }^{1}$ \\ ${ }^{1}$ Kelompok Peneliti Bidang Bidang Ilmu Pengembangan Pertanian Lahan Kering \\ Fakultas Pertanian Universitas Mataram \\ Email ${ }^{*}$ : bambang.bs@unram.ac.id
}

Diterima: Juli 2019

Disetujui: September 2019

\begin{abstract}
One of the advantages of Moringa is the proximate component of seeds, which can be used as a seed material and also as an industrial processed base material, which its quality is largely determined by method to process the seeds. This study aims to determine the performance of proximate components of Moringa seeds in various drying methods. The drying techniques used in this experiment are by using oven at $60 \pm 3^{\circ} \mathrm{C}$, oven at 105 $\pm 3^{\circ} \mathrm{C}$, drying with sunlight, and drying with wind flow (dry wind). Each drying treatment used $250 \mathrm{~g}$ of Moringa seeds with three replications. Proximate analysis of Moringa seeds was carried out using the standard method by Association of Official Analytical Chemists. The results showed that the drying technique had a significant effect on the proximate components of Moringa seeds due to differences in drying temperatures. There was a decrease in the fat and protein content of the seeds as drying temperatures increased, especially in oven drying techniques $\left(60^{\circ} \mathrm{C}\right.$ and $\left.100^{\circ} \mathrm{C}\right)$. Wind drying techniques and sun drying were better techniques for drying Moringa seeds.
\end{abstract}

Keywords: carbohydrates, fat, protein, sun drying, wind

\begin{abstract}
ABSTRAK
Salah satu keunggulan tanaman kelor adalah komponen proksimat biji, yang dapat digunakan sebagai sumber benih dan juga sebagai bahan dasar olahan industri, yang kualitasnya sangat ditentukan oleh cara memproses biji-biji tersebut. Penelitian ini bertujuan mengetahui keragaan komponen proksimat biji kelor pada berbagai cara pengeringan biji. Teknik pengeringan tersebut adalah pengeringan dengan menggunakan oven pada $60 \pm 3^{\circ} \mathrm{C}$ dan pada $105 \pm 3^{\circ} \mathrm{C}$, pengeringan dengan sinar matahari, dan pengeringan dengan aliran angin (kering angin). Sebanyak $250 \mathrm{~g}$ sampel biji digunakan pada setiap teknik pengeringan dengan tiga ulangan. Analisis proksimat biji kelor dilakukan dengan menggunakan metode standar oleh Association of Official Analytical
\end{abstract}


Chemists. Hasil penelitian menunjukkan teknik pengeringan berpengaruh nyata terhadap komponen proksimat biji kelor akibat ada perbedaan suhu pengeringan. Terjadi penurunan kandungan lemak dan protein biji seiring dengan semakin meningkat suhu pengeringan terutama pada teknik pengeringan oven $\left(60^{\circ} \mathrm{C}\right.$ dan $\left.100^{\circ} \mathrm{C}\right)$. Teknik pengeringan kering angin dan pengeringan dengan sinar matahari adalah teknik yang lebih baik untuk pengeringan biji kelor.

Kata kunci: angin, karbohidrat, lemak, pengeringan sinar matahari, protein

\section{PENDAHULUAN}

\section{Latar Belakang}

Kelor (Moringa oleifera Lam.) adalah tanaman asli dari wilayah atau kawasan Afrika dan Asia yang merupakan satu-satunya genus dalam famili tanaman berbunga Moringaceae. Kelor mengandung berbagai unsur nutrisi dan vitamin yang sangat baik untuk manusia maupun hewan ternak (Adejumo dan Abayomi, 2012). Biji kelor dapat digunakan sebagai bahan penjernih air kotor (Mustapha, dkk., 2012), dan juga merupakan sumber obat yang berguna (Busani, dkk., 2011), serta merupakan sumber minyak yang dapat dipakai sebagai alternatif biodiesel (Dorria, dkk., 2016; Amouri, dkk., 2012).

Selama ini, tanaman kelor telah tumbuh dan berkembang tanpa sentuhan teknologi budidaya yang memadai di berbagai wilayah di Pulau Lombok. Namun, sehubungan dengan semakin populernya tanaman ini yang dikarenakan manfaat yang banyak dari sebagai sumber makanan sehat hingga sumber alternatif bahan bakar minyak, maka upaya awal dalam program pengembangannya adalah menginventarisasi tegakan-tegakan yang unggul dari suatu populasi yang ada. Salah satu komponen keunggulan tanaman kelor adalah komponen kimia (proximate) dari biji. Biji dapat dipandang sebagai sumber bahan tanam yaitu benih dan juga sebagai bahan olahan industri. Kualitas kandungan biji sangat ditentukan oleh bagaimana cara memproses biji-biji tersebut, salah satunya adalah pengeringan biji sebelum dilakukan proses selanjutnya, baik diproses langsung ataupun disimpan terlebih dahulu.

Pengeringan terhadap bahan hidup merupakan salah satu proses yang penting dan menantang, karena sejumlah besar produk pertanian dan juga makanan mengalami setidaknya satu langkah pengeringan selama proses produksinya (Wankhade, dkk., 2013). Pengeringan atau dehidrasi produk digambarkan sebagai proses yang melibatkan penghilangan secara termal terhadap zat yang mudah menguap untuk mendapatkan padatan kering (Xiao, dkk., 2010). Tujuan utama pengeringan produk yang berasal dari tanaman, terutama biji, adalah untuk meningkatkan umur simpan, meningkatkan kualitasnya, menyederhanakan penanganan, penyimpanan, dan pengangkutan produk, serta untuk mempersiapkan produk ke proses selanjutnya.

Teknik pengeringan produk tanaman pertanian yang dilakukan di sebagian besar wilayah tropis dengan teknik pengeringan matahari (Lasisi, dkk., 2013). Teknik ini tentu akan menghasilkan bahan hasil pengeringan yang besar kemungkinan terkontaminasi oleh debu, kotoran dan juga mikroorganisme. Oleh karena itu, perlu diperkenalkan atau diuji coba penggunaan teknik pengeringan lainnya yang dapat mempertahankan kuantitas dan kualitas biji dan senyawasenyawa penting yang terkandung di dalamnya.

\section{Tujuan}

Artikel ini memaparkan hasil penelitian pendahuluan yang bertujuan mengetahui keragaan komponen 
proksimat biji kelor dari berbagai cara pengeringan biji. Hasil penelitian ini diharapkan memberikan informasi yang memadai tentang teknik pengeringan biji yang cocok yang akan memberikan retensi komponen proksimat secara maksimum untuk biji kelor.

\section{METODE PENELITIAN}

\section{Pengumpulan dan persiapan bahan baku (biji)}

Biji kelor yang digunakan merupakan biji yang diperoleh dari 10 tegakan tanaman kelor dewasa yang tumbuh subur dan sehat di halaman rumah penduduk di Dusun Panggung, Kabupaten Lombok Utara, NTB, pada posisi geografis $\quad 8^{\circ} 16^{\prime} 15.02$ ' $\mathrm{S}$, $116^{\circ} 17^{\prime} 34.02^{\prime}$ 'T, elevasi $120 \mathrm{~m}$. Buah yang telah masak (berwarna coklat) dipetik dan dikumpulkan. Biji yang dikumpulkan hanya biji yang berada pada posisi pangkal dan tengah pada buah kelor (Santoso dan Parwata, 2017). Sejumlah 50-60 buah (pod) diambil dari masingmasing tanaman, dan biji-biji yang diambil memiliki kriteria berwarna coklat, bernas, dan tidak rusak. Biji-biji tersebut dicampur dan kemudian di-simpan dalam kantong plastik poli-propilen, dan siap digunakan dalam percobaan. Kondisi lingkungan saat satu bulan menjelang hingga saat polong (biji) dipanen memiliki kelembaban relatif udara berkisar antara $75-85 \%$ dan suhu udara $28-31^{\circ} \mathrm{C}$.

\section{Metode pengeringan}

Sebanyak $250 \mathrm{~g}$ sampel biji dipersiapkan untuk digunakan pada setiap percobaan pengeringan dan setiap percobaan dibuat tiga ulangan.

\section{a. Pengeringan oven}

Biji kelor dikeringkan dengan menggunakan oven di Laboratorium Agronomi dan Hortikultura Fakultas Pertanian Universitas Mataram. Ada dua perlakuan yang diujikan yaitu pengeringan oven pada suhu $60 \pm 3^{\circ} \mathrm{C}$ dan pada
$105 \pm 3^{\circ} \mathrm{C}$, selama waktu tertentu untuk mencapai kadar air biji $8 \%$.

\section{b. Pengeringan sinar matahari}

Biji kelor ditempatkan di nampan dan diatur dengan ketebalan satu lapisan biji. Nampan berisi biji diletakkan di atas meja dan di bawah sinar matahari langsung. Udara dibiarkan bersirkulasi bebas. Biji kelor dikeringkan hingga mencapai kadar air 8\%. Pengukuran kadar air dilakukan setiap interval 3 jam.

c. Pengeringan angin (kering angin)

Biji kelor ditempatkan di nampan dan diatur dengan ketebalan satu lapisan biji. Nampan berisi biji ditempatkan di atas meja pada bilik beratap tanpa dinding agar dapat menfasilitasi gerakan atau aliran angin bebas namun tidak terkena sinar matahari langsung. Biji kelor dikeringkan hingga mencapai kadar air 8\%. Pengukuran kadar air dilakukan setiap interval 3 jam.

\section{Analisis proksimat biji}

Analisis proksimat biji kelor dilakukan dengan menggunakan metode standar oleh AOAC (2000), meliputi:

a. Kadar air $\left(\mathrm{K}_{\mathrm{a}}\right)$

Sampel biji sebanyak $5 \mathrm{~g}\left(\mathrm{~W}_{1}\right)$ dimasukkan ke dalam cawan petri yang sudah diketahui beratnya $\left(\mathrm{W}_{2}\right)$, lalu dimasukkan ke dalam oven pada suhu $105^{\circ} \mathrm{C}$ selama 3 jam. Sampel dikeluarkan dari oven dan didinginkan dalam desikator selama 30 menit hingga mencapai suhu ruang, kemudian ditimbang berat akhir $\left(\mathrm{W}_{3}\right)$ dan dihitung kadar air dengan persamaan 1 .

$K_{a}=\frac{\left(W_{1}+W_{2}\right)-W_{3}}{W_{1}} \times 100$

b. Kadar $\mathrm{abu}\left(\mathrm{K}_{\mathrm{ab}}\right)$

Kandungan abu biji me-rupakan residu anorganik yang tersisa setelah penghancuran bahan organik atau kandungan mineral yang ada dalam biji. Sampel sebanyak $5 \mathrm{~g}\left(\mathrm{~W}_{1}\right)$ dimasukkan ke dalam cawan porcelin kemudian dibakar 
di dalam tungku selama 3 jam pada suhu $650^{\circ} \mathrm{C}$. Setelah 3 jam sampel dikeluarkan dan didinginkan dalam desikator selama 30 menit, kemudian berat akhir (abu) $\left(\mathrm{W}_{2}\right)$ ditimbang. Kadar abu dihitung dengan persamaan 2 .

$K_{a}=\frac{W_{2}}{W_{1}} \times 100$

\section{c. Kadar lemak kasar $\left(\mathrm{K}_{\mathrm{k}}\right)$}

Kadar lemak kasar dianalisa menggunakan metode ekstraksi Soxchlet dengan pelarut heksane. Sebanyak $5 \mathrm{~g}$ sampel biji $\left(\mathrm{W}_{1}\right)$ dibungkus dengan kertas saring, lalu dimasukkan ke dalam tabung soxchlet dengan pelarut heksan sebanyak $200 \mathrm{ml}$, kemudian di soxchlet selama 4 jam. Heksane yang telah mengandung ekstrak lemak biji kelor dipindahkan ke dalam erlenmeyer kemudian diekstraksi dengan metode destilasi. Hasil ekstraksi dikeringkan dalam oven $100^{\circ} \mathrm{C}$ sampai berat konstan. Berat residu dinyatakan sebagai berat lemak $\left(\mathrm{W}_{3}\right)$, dan kadar lemak dihitung dengan persamaan 3 .

$\mathrm{K}_{\mathrm{lk}}=\left(\mathrm{W}_{3} / \mathrm{W}_{1}\right) \times 100$

\section{c. Kadar serat kasar $\left(\mathbf{K}_{\text {sk }}\right)$}

Serat kasar adalah residu organik yang tersisa setelah sampel makanan diolah dalam kondisi standar dengan asam standar dan larutan alkali. Sebanyak $5 \mathrm{~g}$ sampel biji $\left(\mathrm{W}_{1}\right)$ dan kemudian dibungkus dengan kertas saring yang telah diketahui beratnya. Sampel terbungkus tersebut dimasukkan ke dalam labu destilasi kemudian dimasukkan $\mathrm{HCl} \quad 0,2 \quad \mathrm{M}$ sebanyak $200 \mathrm{ml}$, dididihkan selama 30 menit, setelah itu sampel diangkat dan dibilas dengan akuades mendidih sampai 5 kali bilasan, sampai air tidak bersifat asam. Kemudian sampel ditambahkan 200 ml $\mathrm{NaOH}$ 0,3 M kemudian dididihkan selama 30 menit. Sampel kemudian diangkat dan dibilas dengan akuades mendidih sebanyak 5 kali sampai air bilasan tidak bersifat basa. Setelah itu dikeringkan di oven $105^{\circ} \mathrm{C}$ selama 1-2 jam, kemudian dimasukkan ke desikator. Selisih kertas saring pertama $\left(\mathrm{W}_{2}-\mathrm{W}_{3}\right)$ ditimbang, dan kadar serat kasar dihitung dengan persamaan 4 .

$K_{s k}=\frac{W_{2}-W_{3}}{W_{1}} \times 100$

\section{d. Kadar protein $\left(\mathrm{K}_{\mathrm{p}}\right)$}

Protein kasar ditentukan dengan metode Kjeldahl. Sampel ditimbang sebanyak $5 \mathrm{~g}$ dan dimasukkan ke dalam khjedal, lalu ditambahkan 5 g NaSO4; 0,2 g CuSO4; dan $20 \mathrm{ml} \mathrm{H} 2 \mathrm{SO} 4$ pekat lalu dicampur dan didestruksi. Pemanas dihentikan setelah cairan menjadi jernih, setelah didinginkan kemudian ditambahkan $100 \mathrm{ml}$ akuades, lalu ditambahkan larutan $\mathrm{NaOH} 45 \%$ sampai cairan bersifat basa (dites dengan kertas lakmus/warna biru). Bahan kemudian didestilasi (mulai dari pemanasan rendah), disiapkan erlenmeyer berisi larutan $\mathrm{HCl}$ $0,1 \mathrm{M}$ sebanyak $50 \mathrm{ml}$ yang sudah diberi indikator fenoftalein $1 \%$ sebanyak 2-3 tetes, untuk menampung destilat yang keluar dari sampel (destilasi diakhiri setelah volume destilat mencapai $75 \mathrm{ml}$ ). Destilat $(\mathrm{HCl} 0,1 \mathrm{M})$ dititrasi dengan larutan $\mathrm{NaOH}$ 0,1 M. Kemudian dicatat $\mathrm{ml}$ $\mathrm{NaOH}$ yang tercapai dan kemudian kadar protein dihitung dengan persamaan 5 .

$K p=\frac{A-B}{2 \times 10} \times N \times 14,008$

Dimana:

$\mathrm{A}=$ volume $\mathrm{NaOH}$ blanko $(\mathrm{ml})$

$\mathrm{B}=$ volume $\mathrm{NaOH}$ contoh

$\mathrm{N}=$ Normalitas $\mathrm{NaOH}$

\section{e. Kadar karbohidrat}

Kadar karbohidrat Ditetapkan berdasarkan perhitungan 100 dikurangi besaran nilai dari penjumlahan kadar protein, kadar lemak, kadar abu, dan kadar serat.

\section{HASIL DAN PEMBAHASAN}

Keragaan hasil analisis proksimat biji kelor dua aksesi pulau Lombok (LU-1 
dan LT-1), komponennya dipengaruhi secara nyata $(\mathrm{p}<0,05)$ oleh teknik atau cara pengeringan. Namun, komponen proksimat di antara aksesi berbeda tidak nyata $(\mathrm{p}>0,05)$.

Pada Tabel 1, tampak bahwa kadar air awal biji kelor kedua aksesi relatif berbeda, yaitu kadar air biji LT-1 relatif lebih tinggi dari LU-1. Namun untuk mencapai kadar air biji yang aman bagi penyimpanan (sekitar 8 persen) dengan berbagai teknik pengeringan pada penelitian ini membutuhkan waktu yang berbeda. Hasil analisis menunjukkan lama waktu pengeringan berbeda nyata di antara teknik pengeringan yang digunakan. Pengeringan dengan meng-gunakan oven pada $100^{\circ} \mathrm{C}$ merupakan teknik pengeringan tercepat $(5,4$ jam untuk aksesi LU-1 dan 6,6 jam untuk aksesi LT-1) untuk mendapatkan kadar air biji kelor 8 persen. Sementara itu, teknik pengeringan kering angin merupakan teknik pengeringan biji kelor yang terlama, yaitu membutuhkan waktu sekitar 61,1 jam untuk aksesi LU-1 dan 65,1 jam untuk aksesi LT-1.

Pada Tabel 1, tampak bahwa pengeringan biji kelor dengan cara kering angin hingga tercapai kadar air tertentu (dari kadar air 12,8 \pm 0,05 menuju kadar air $8,4 \pm 0,01)$ merupakan teknik pengeringan yang membutuhkan waktu paling lama $(65,1 \pm 0,11)$. Teknik ini merupakan teknik pengeringan alami, tanpa adanya rekayasa pengaturan terhadap sumber panas yang terlibat dalam pengurangan (pembuangan) kelembaban (air) yang terkandung dalam biji. Hal ini juga dilaporkan Franke, dkk., (2008), pada pengeringan secara alami biji sorgum. Lamanya waktu pengeringan dengan teknik alami ini mungkin saja dapat membahayakan biji. Kontaminasi dengan debu termasuk mikroorganisme yang terikut akan mudah menurunkan biji tersebut. Adanya perubahan atau naik- turunnya suhu karena perubahan cuaca juga akan berpengaruh buruk pada biji akibat perubahan laju respirasi dan perubahan kelembaban udara di sekitar biji.

Keragaan komponen proksimat biji kelor kedua aksesi Pulau Lombok pada berbagai teknik pengeringan disajikan pada Tabel 2. tampak bahwa teknik pengeringan berpengaruh nyata pada kadar protein, karbohidrat, dan lemak kasar; namun berpengaruh tidak nyata pada kadar serat kasar dan kadar abu biji kedua aksesi.

Hasil penelitian pendahuluan ini menunjukkan bahwa komponen proksimat biji kelor dua aksesi Pulau Lombok berbeda tidak nyata, namun keduanya relatif berbeda dengan komponen proksimat biji kelor dari berbagai negara yang dilaporkan beberapa peneliti (dalam literatur). Komponen proksimat biji kelor provenan Pakistan dilaporkan Anwar dan Rashid (2007) meliputi kadar lemak atau minyak $(34,80-40,39 \%)$, protein $(29,36-$ $31,65 \%)$, serat $(7,20-7,54 \%)$, dan abu (6,53-6,60\%). Aremu dan Akintola (2014) melaporkan bahwa biji kelor di Nigeria mengandung protein $(31,5 \%)$, karbohidrat $(20,7 \%)$, lemak $(32,2 \%)$, serat kasar $(10,3 \%)$, dan abu $(9,6 \%)$.

Hasil penelitian ini juga menunjukan bahwa terjadi penurunan kandungan minyak (lemak) biji seiring dengan semakin meningkat suhu pengeringan akibat perbedaan dari teknik pengeringan yang digunakan. Demikian pula halnya dengan kandungan protein biji, terjadi penurunan kadar seiring dengan meningkatnya suhu pengeringan. Fenomena ini juga dilaporkan Adejumo, dkk., (2013), bahwa hasil minyak untuk biji kelor yang terkena panas pada suhu $100^{\circ} \mathrm{C}, 130^{\circ} \mathrm{C}$ dan $150^{\circ} \mathrm{C}$ dalam proses pengeringannya masing-masing adalah $33,7 \%$; $32,2 \%$; dan $30,9 \%$. 
Tabel 1. Kadar air awal dan akhir, serta lama waktu pengeringan pada berbagai teknik pengeringan biji kelor dua aksesi Pulau Lombok

\begin{tabular}{lccc}
\hline Teknik Pengeringan & $\begin{array}{c}\text { Kadar Air } \\
\text { Biji } \\
\text { Awal }(\%)\end{array}$ & $\begin{array}{c}\text { Kadar Air Biji } \\
\text { Setelah Pengeringan } \\
(\%)^{*}\end{array}$ & $\begin{array}{c}\text { Lama waktu } \\
\text { Pengeringan } \\
(\text { jam) })^{*}\end{array}$ \\
\hline Aksesi LU-1 & $12,1 \pm 0,01$ & $8,0 \pm 0,02$ & $9,2 \pm 0,72^{\mathrm{b}}$ \\
Oven $60^{\circ} \mathrm{C}$ & $11,3 \pm 0,04$ & $8,1 \pm 0,02$ & $5,4 \pm 0,91^{\mathrm{a}}$ \\
Oven $105^{\circ} \mathrm{C}$ & $11,6 \pm 0,03$ & $7,9 \pm 0,05$ & $54,6 \pm 0,47^{\mathrm{c}}$ \\
Sinar matahari & $11,9 \pm 0,01$ & $8,0 \pm 0,03$ & $61,1 \pm 0,24^{\mathrm{d}}$ \\
Kering angin & $13,3 \pm 0,02$ & $8,1 \pm 0,03$ & \\
\hline Aksesi LT-1 & $12,5 \pm 0,08$ & $8,3 \pm 0,02$ & $9,7 \pm 0,55^{\mathrm{b}}$ \\
Oven $60^{\circ} \mathrm{C}$ & $13,1 \pm 0,03$ & $8,0 \pm 0,05$ & $6,6 \pm 0,82^{\mathrm{a}}$ \\
Oven $105^{\circ} \mathrm{C}$ & & & $56,6 \pm 0,34^{\mathrm{c}}$ \\
Sinar matahari & $12,8 \pm 0,05$ & $8,4 \pm 0,01$ & $65,1 \pm 0,11^{\mathrm{d}}$ \\
Kering angin & & & \\
\hline
\end{tabular}

Keterangan: *(berbeda tidak nyata), **(berbeda nyata) pada $\mathrm{p}=0.05$ dengan $\mathrm{n}=3$. Angka-angka pada kolom yang sama, yang diikuti huruf yang sama berbeda tidak nyata.

Tabel 2. Keragaan komponen proksimat biji pada berbagai teknik pengeringan biji kelor dua aksesi Pulau Lombok

\begin{tabular}{lccccc}
\hline Teknik Pengeringan & $\begin{array}{c}\text { Protein } \\
* *\end{array}$ & $\begin{array}{c}\text { Karbohidrat } \\
* *\end{array}$ & $\begin{array}{c}\text { Lemak kasar } \\
* *\end{array}$ & $\begin{array}{c}\text { Serat Kasar } \\
*\end{array}$ & $\begin{array}{c}\text { Abu } \\
*\end{array}$ \\
\hline Aksesi LU-1 & & & & & \\
Kering Panen & $32,5 \pm 0,2^{\mathrm{b}}$ & $21,3 \pm 0,9^{\mathrm{a}}$ & $31,9 \pm 0,5^{\mathrm{b}}$ & $10,4 \pm 0,3$ & $4,1 \pm 0,3$ \\
Oven $60^{\circ} \mathrm{C}$ & $29,1 \pm 0,3^{\mathrm{a}}$ & $26,4 \pm 0,1^{\mathrm{b}}$ & $29,8 \pm 0,4^{\mathrm{a}}$ & $8,8 \pm 0,9$ & $5,5 \pm 0,1$ \\
Oven $105^{\circ} \mathrm{C}$ & $28,6 \pm 0,5^{\mathrm{a}}$ & $28,4 \pm 0,1^{\mathrm{b}}$ & $28,2 \pm 0,9^{\mathrm{a}}$ & $8,2 \pm 0,7$ & $5,9 \pm 0,1$ \\
Sinar matahari & $30,7 \pm 0,3^{\mathrm{ab}}$ & $23,3 \pm 0,8^{\mathrm{a}}$ & $31,3 \pm 0,2^{\mathrm{b}}$ & $10,6 \pm 0,1$ & $3,8 \pm 0,8$ \\
Kering angin & $31,9 \pm 0,2^{\mathrm{b}}$ & $22,8 \pm 0,8^{\mathrm{a}}$ & $31,7 \pm 0,4^{\mathrm{b}}$ & $10,7 \pm 0,1$ & $3,3 \pm 0,9$ \\
\hline Aksesi LT-1 & & & & & \\
Kering Panen & $31,2 \pm 0,2^{\mathrm{b}}$ & $20,1 \pm 0,8^{\mathrm{a}}$ & $30,8 \pm 0,4^{\mathrm{b}}$ & $10,3 \pm 0,1$ & $5,3 \pm 0,2$ \\
Oven 60 C & $28,8 \pm 0,7^{\mathrm{a}}$ & $25,6 \pm 0,4^{\mathrm{b}}$ & $28,9 \pm 0,3^{\mathrm{a}}$ & $8,9 \pm 0,8$ & $5,1 \pm 0,2$ \\
Oven $105^{\circ} \mathrm{C}$ & $28,1 \pm 0,8^{\mathrm{a}}$ & $27,2 \pm 0,1^{\mathrm{b}}$ & $27,8 \pm 0,8^{\mathrm{a}}$ & $8,4 \pm 0,8$ & $6,5 \pm 0,1$ \\
Sinar matahari & $29,7 \pm 0,7^{\mathrm{ab}}$ & $23,1 \pm 0,6^{\mathrm{a}}$ & $29,7 \pm 0,4^{\mathrm{ab}}$ & $10,5 \pm 0,1$ & $3,4 \pm 0,9$ \\
& & & & \\
Kering angin & $30,4 \pm 0,3^{\mathrm{b}}$ & $21,7 \pm 0,8^{\mathrm{a}}$ & $30,1 \pm 0,6^{\mathrm{b}}$ & $10,4 \pm 0,2$ & $3,9 \pm 0,6$ \\
\hline
\end{tabular}

Keterangan: *(berbeda tidak nyata), **(berbeda nyata) pada $\mathrm{p}=0.05$ dengan $\mathrm{n}=3$. Angka-angka pada kolom yang sama, yang diikuti huruf yang sama berbeda tidak nyata.

Jadi, sehubungan dengan penelitian ini, maka tersedia beberapa teknik pengeringan biji kelor yang dapat digunakan. Khususnya pada daerah tropika seperti di kawasan Pulau Lombok, NTB memungkinkan untuk menggunakan teknik pengeringan dengan hanya menebar rata biji-biji pada hamparan (wadah atau alas yang bersih) untuk dikeringkan dengan menggunakan (memanfaatkan) sinar matahari secara langsung ataupun hanya dengan pengeringan menggunakan hembusan angin (kering angin). Namun demikian, sebaiknya biji-biji kelor yang dikeringkan untuk keperluan penyimpanan sebelum digunakan atau diproses lebih lanjut, hindari pengeringan pada suhu yang terlalu panas dan langsung terpapar sinar matahari. Pada pengeringan ini menyebabkan kandungan minyak dan protein biji relatif menurun. Penelitian ini sejalan dengan Siddique dan Wright (2003). Pengeringan pada suhu yang 
tinggi seperti halnya penggunaan oven tentu akan mengeringkan biji-biji kelor hingga kadar air tertentu yang diinginkan dapat dengan cepat, namun kemungkinan terjadinya kerusakan pada komponen proksimat biji akan terjadi. Pada penelitian ini dijumpai bahwa pengeringan dengan menggunakan oven menyebabkan kadar lemak, protein, dan karbohidrat menurun atau lebih rendah dibandingkan dengan teknik pengeringan lainnya. Pengeringan pada suhu yang tinggi menyebabkan biji menjadi rusak dikarenakan kandungan air berkurang (hilang) dengan cepat dan juga dikarenakan kerusakan fisik suhu tinggi. Dikatakan oleh Trisnawati, dkk., (2014) bahwa pengeringan metode oven merupakan pengeringan dengan menggunakan udara panas, yang menguapkan air dari bahan yang dapat saja lebih cepat ataupun lebih lama tergantung bahan yang dikeringkan.

Pada tingkat industri yang relatif modern dan menibatkan sejumlah besar bahan olahan, tentunya teknik pengeringan buatan lebih sering digunakan, dan lebih mudah beradaptasi dengan kebutuhan pelaksanaan suatu proses produksi sehubungan dengan lebih cepat dan efisien dalam hal membuang kandungan air dalam bahan (biji). Teknik ini dapat diarahkan atau diatur secara mekanis untuk dapat menghasilkan kualitas biji (benih) pada kondisi tertentu yang dapat dikuasai. Selain itu, keuntungan utama dari teknik buatan atau mekanis ini adalah untuk memungkinkan dilakukannya pengendalian kebutuhan suhu, aliran udara udara pengeringan, dan waktu pemaparan biji ke udara panas, dan beberapa faktor mendasar lainnya untuk memastikan proses berjalan secara efektif dan efisiensi. Oleh karena itu, beberapa faktor harus dipertimbangkan ketika memilih di antara berbagai teknik pengeringan biji yang ada. Faktor-faktor tersebut termasuk volume biji (benih) yang dipanen secara efektif, kecepatan panen, waktu pengeringan, konsumsi (kebutuhan) energi, tujuan akhir biji (benih), selain dari aspek yang berhubungan dengan manusia seperti pengetahuan teknologi dan daya beli produsen.

\section{KESIMPULAN DAN SARAN}

\section{Kesimpulan}

Teknik pengeringan berpengaruh nyata terhadap komponen proksimat biji kelor akibat perbedaan suhu pengeringan. Terjadi penurunan kandungan minyak (lemak) dan protein biji seiring dengan semakin meningkat suhu pengeringan terutama pada teknik pengeringan oven $\left(60^{\circ} \mathrm{C}\right.$ dan $\left.100^{\circ} \mathrm{C}\right)$. Teknik pengeringan kering dengan sinar matahari adalah teknik yang lebih baik untuk pengeringan biji kelor. Metode ini dapat mempertahankan komponen proksimat yang lebih baik seperti protein, lemak, dan komponen proksimat lainnya disbandingkan dengan teknik pengeringan menggunakan oven, dengan memperhatikan wadah yang dapat mencegah kontaminasi oleh kotoran dan debu.

\section{Saran}

Perlu penelitian lanjutan untuk mengetahui viabilitas biji (benih) hasil pengeringan dan pengujian periode penyimpanan biji.

\section{UCAPAN TERIMAKASIH}

Terima kasih disampaikan kepada Universitas Mataram atas penyediaan dana penelitian ini melalui Skim Penelitian Peningkatan Kapasitas bersumber dari BLU (PNBP) Unram tahun 2019.

\section{DAFTAR REFERENSI}

Adejumo, B.A., \& Abayomi, D.A. (2012). Effect of Moisture content on some physical properties of Moringa oleifera seed. Journal of Agriculture 
and Veterinary Science. Vol. 1:1221.

Adejumo, B.A., Alakowe, A.T., \& Obi, D.E. (2013). Effect of Heat Treatment on the Characteristics and Oil Yield of Moringa Oleifera Seeds. The International Journal of Engineering and Science. Vol. 2 (1): 232-239.

Amouri, M., Zaid, A., Aziza, M.A., \& Zanndouche, O. (2012). Life cycle analysis of Moringa oleifera biodiesel. Congres International sur les Energies Renouvelable set Environment. 19-21 Mart, 2012. Hammamet, Tunisie.

Anwar, F., \& Rashid, U. (2007). Physicochemical characteristics of Moringa oleifera seeds and seed oil from a wild provenance of Pakistan. Pak. J. Bot. Vol. 39 (5): 1443-1453.

AOAC (Association of Official Analytical Chemists). (2000). Official Method of Analysis of AOAC International. 17th ed. Association of Official Analytical Chemists Inc. Horwitz, Willium, 2,200 pp.

Aremu, A.K., \& Akintola, A. (2014). Effects of some drying methods on nutritional characteristics of Moringa (Moringa Oleifera) seeds. 2014 4th International Conference on Biotechnology and Environment Management IPCBEE vol.75 (2014) (C) (2014) IACSIT Press, Singapore. DOI: 10.7763/IPCBEE. 2014. V75. 12

Busani, M., Patrick, J.M., Amold, H., \& Voster, M. (2011). Nutritional characterization of Moringa leaves. African Journal of Biotechnology. Vol. 10 (60): 12925-12933.

Dorria, M.M.A., Mahfouze, H.A., Ali, E.A.M., \& Abdelrahman, H.H. (2016). Morphological, Biochemical and Molecular Studies on Jatropha curcas Seedlings. Int. J. of Chem. Tech. Research. Vol. 9 (07): 37-45.
Franke, L.B., Torres, M.A.P., \& Lopes, R.R. (2008). Performance of different drying method and their effects on the physiological quality of grain sorghum seeds. Revista Brasileira de Sementes. Vol. 30 (3): 177-184.

Lasisi, D., Balogun, L.A., Nasirudeen, A.R., Ogunsola, F.O., Adesola, A.A., \& Adeyeye, T.A. (2013). Comparative study of effects of drying methods on the quality of cocoa beans. Proceedings of The Nigerian Institution of Agricultural Engineers. Vol. 34: 579-583.

Mustapha, H.B., Jonan, C.A., Suleyman A.M. (2012). Kinetics of water disinfection with Moringa seed extract. Journal of Environment and Earth Science. Vol. 2 (7): 224-231.

Santoso, B.B., \& Parwata, I.G.M.A. (2017). Viabilitas biji dan pertumbuhan bibit kelor (Moringa oleifera Lam.). Jurnal Sains Teknologi \& Lingkungan. Vol. 3 (2):1-8.

Siddique, A.B., \& Wright, D. (2003). Effect of different seed drying methods on moisture percentage and seed quality (viability and vigour) of Pea Seed (Pisum sativum L.). Pakistan Journal of Agronomy. Vol. 2 (4): 201-208.

Trisnawati, W., Suter, K., Suastika, K., \& Putra, N.K. (2014). Pengaruh metoda pengeringan terhadap kandungan antioksidan, serat pangan, dan komposisi gizi tepung labu kuning. Jurnal Aplikasi Teknologi Pangan. Vol. 3 (4): 135140.

Wankhade, P., Sapkal, R., \& Sapkal, V. 2013. Drying characteristics of okra slices on drying in hot air dryer. Procedia Engineering. Vol. 51:371374.

Xiao, H.W., Gao, Z.J., Lin. H., \& Yang, W.X. (2010). Air impingement drying characteristics and quality of 
carrot cubes, Journal of Food

Process Engineering. Vol. 33(5):

899-918. 